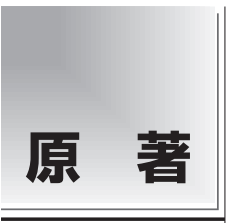

\title{
脳形態変化のパターン分類と可視化のための 画像データマイニング
}

村川彩希 $^{1}$ 生田理恵 ${ }^{2,3}$ 内山良一 ${ }^{4}$ 白石順二 ${ }^{4}$

論文受付

2015 年 3 月 9 日

論文受理

2015 年 12 月 24 日

Code No. 535

\author{
1 熊本大学大学院保健学教育部 \\ 2 熊本大学医学部保健学科放射線技術学専攻 \\ 3 大阪大学医学部附属病院医療技術部放射線部門 \\ ${ }^{4}$ 熊本大学生命科学研究部先端生命医療科学部門
}

\section{緒 言}

超高齢化社会を迎えた日本では，認知症患者が増加 傾向にある ${ }^{1)}$. 認知症のなかでもアルツハイマー型認 知症 (Alzheimer's disease: AD) は全体の約半数を占め る1). AD の早期診断を支援するために, magnetic resonance $(M R)$ 画像を分析して $A D$ に関する画像特 徵を医師に提示する手法に関する研究が行われてい $る^{225)}$ ，脳の白質と死白質を領域分割する手法 ${ }^{2)}$, 脳脊 髄液の抽出法 ${ }^{3)}$, 皮質の厚みの測定法 ${ }^{4)}$ などである.
これらの研究は脳の特定の部位の特徴を定量化する手 法に関するものである。一方, 脳形態標準化処理を行 うことで脳全体の解剖学的な空間分布の特徵を可視化 する研究も行われている. Voxel-based specific regional analysis for Alzheimer's diseases (VSRAD) で は, statistical parametric mapping(SPM)を用いて健 常者から正常脳を作成し, 正常脳からの変化を Z スコ アで表示し評価している5.

現在，多くの病院では病院情報システムが稼働し，

\section{Image Data Mining for Pattern Classification and Visualization of Morphological Changes in Brain MR Images}

\author{
Saki Murakawa, ${ }^{1 *}$ Rie Ikuta, ${ }^{2}{ }^{3}$ Yoshikazu Uchiyama, ${ }^{4}$ and Junji Shiraishi ${ }^{4}$ \\ ${ }^{1}$ Graduate School of Health Science, Kumamoto University \\ ${ }^{2}$ Course of Radiological Science, School of Health Science, Kumamoto University \\ ${ }^{3}$ Division of Radiology, Department of Medical Technology, Osaka University Hospital \\ ${ }^{4}$ Department of Medical Physics, Faculty of Life Science, Kumamoto University
}

Received March 9, 2015; Revision accepted December 24, 2015

Code No. 535

\section{Summary}

Hospital information systems (HISs) and picture archiving and communication systems (PACSs) are archiving large amounts of data (i.e., "big data") that are not being used. Therefore, many research projects in progress are trying to use "big data" for the development of early diagnosis, prediction of disease onset, and personalized therapies. In this study, we propose a new method for image data mining to identify regularities and abnormalities in the large image data sets. We used 70 archived magnetic resonance (MR) images that were acquired using threedimensional magnetization-prepared rapid acquisition with gradient echo (3D MP-RAGE). These images were obtained from the Alzheimer's disease neuroimaging initiative (ADNI) database. For anatomical standardization of the data, we used the statistical parametric mapping (SPM) software. Using a similarity matrix based on crosscorrelation coefficients (CCs) calculated from an anatomical region and a hierarchical clustering technique, we classified all the abnormal cases into five groups. The $\mathrm{Z}$ score map identified the difference between a standard normal brain and each of those from the Alzheimer's groups. In addition, the scatter plot obtained from two similarity matrixes visualized the regularities and abnormalities in the image data sets. Image features identified using our method could be useful for understanding of image findings associated with Alzheimer's disease.

Key words: image data mining, anatomical standardization, clustering, Alzheimer's disease

\footnotetext{
* Proceeding author
} 
画像，検査データなどのビッグデータが蓄えられてい る。更に，クラウド技術によって地域の病院との情報 共有も進み，患者の一生涯にわたる医療記録が時系列 で保存される仕組みも整いつつある。これまでの病院 情報システムは，業務の効率化を目指して開発がなさ れてきた。しかし，これからは，病院に眠っている ビッグデー夕を発病の予測・予防, 病気の超早期診断, 個別化治療などに活用するための次世代 information and communication technology (ICT) 医療技術に関す る研究開発が重要である.

そこで本研究では, $\mathrm{AD}$ 症例の MR 画像を対象に, 形態変化のパターンを自動分類, 可視化する画像デー タマイニング技術を提案する。脳形態標準化処理に加 えて, 解剖学的な空間分布の特徵分析にデータマイニ ングを用いた技術を提案する点が先行研究とは異な る、データマイニングとは, データの中にある, 頻出 するパターンや意味のある構造を発見する技術のこと である ${ }^{6,7)}$. 大規模な画像デー夕に含まれる規則性や 異常性が発見できる技術が開発できれば，その成果は 次世代 ICT 医療を支える基盤技術の一つになること が期待される。

以下，2-2節に执いて階層的クラスタリング8) を用 いて画像デー夕間の形態変化パターンの規則性を分類 する手法を提案し，2-3 節において画像デー夕間の規 則性と異常性の関係を可視化し, 異常なパターンを発 見する技術を提案する。

\section{1. 実験試料}

本研究では, 実験試料として, Alzheimer's disease neuroimaging initiative (ADNI) データベース ${ }^{9)}$ を用い た、ADNI データベースには 1879 名のデータがある。 しかし, 撮影条件が異なるためにそのまま解析に用い ることはできない，このことに対処するために ADNI データベースには, 標準セットが用意されている。 こ のうち, 正常セットとして用意されている 52 症例か ら年齢幅を限定し, $71 〜 79$ 歳の 30 症例を実験対象と した，標本数が 30 以上の場合，正規分布を仮定する ことができる。これによって, 70 歳代の画像デー夕を 基準として，基準からの差を分析することになる。 ま た，AD セットとして用意されている 40 症例 (56〜91 歳)を実験対象とした。使用した画像は $3.0 \mathrm{~T} の \mathrm{MR}$ 装置で magnetization-prepared rapid acquisition with gradient echo (MP-RAGE) 撮影法により撮影されたも のである、マトリックスサイズは $256 \times 256$, ボクセル サイズは $1.0 \times 1.0 \times 1.2 \mathrm{~mm}$ であった。 なお，本研究は倫 理審査委員会での承認を得ている.

\section{2. 方 法}

Fig. 1 に提案手法の概要を示す. 脳形態変化を分析 するためには, 大きさや解剖学的位置を合わせる脳形 態標準化処理を行う必要がある。本実験では, SPM8 $8^{10)}$ を用いて脳形態標準化処理を行う。つぎに, 解剖学的な位置合わせが施された画像間の類似度を計 算し，似た画像同士を同じグループに分類する階層的 クラスタリングを適用する。階層的クラスタリングに よって分類された各グループが持っている形態変化の 特徵を可視化するために正常脳との違いを Z スコア マップで表示する。また, 類似度をもとに, 画像デー 夕間の規則性と異常性を散布図で表示する手法も提案 する，散布図で表示することによって，ある画像デー 夕が持っている異常性を可視化することができる，以 下に, 手法の詳細について述べる.

\section{2-1 脸形態標準化}

本研究では, 脳形態変化を分析するための前処理と して, SPM8 を用いて脳形態標準化処理を行った。ま ず，MR 画像を撮影中の体動や心臓の拍動による頭部 の動きを補正する処理である realignmentを行った。 Realignment 処理では, 画像時系列における頭部位置 は変化しないと仮定し, 参照画像(セッション内の一 番最初の画像) とある時点の画像の間で頭部位置を一 致させるように, $\mathrm{X}$ 軸, $\mathrm{Y}$ 軸, $\mathrm{Z}$ 軸方向の平行移動と 回転による剛体変換が行われる. 更に, 動きの補正が なされた画像デー夕に対して再サンプリングを行い， スライスを再構成した ${ }^{11)}$ 。つぎに, 動きの補正された データをSPM8 内で標準脳として用意されている Montreal Neurological Institute (MNI) 標準脳に合致す るように変換する処理である normalizationを加え た ${ }^{11)}$. 本実験では, MNI 標準脳の $\mathrm{T}_{1}$ テンプレート画 像を用いた，以上の処理によって，すべての MR 画像 データの脳形態標準化を行った。標準化された画像 データのサイズは $68 \times 95 \times 79$ に縮小された。この脳形 態標準化処理によって, 解剖学的な位置が同じになる ため, 同じ位置の画素值の比較により形態学的な変化 を分析することができる。

\section{2-2 形態変化の類似度の計算と分類}

前節の処理によって, すべての画像データの解剖学 的位置が同じになっていると仮定できるので, 画像に 関心領域 (region of interest: ROI)を設定し, 画像デー 夕間の類似度を計算することで, 形態的な規則性や異 常性を分析することが可能となる。本研究では, 類似 度の計算に相互相関係数を採用した。相互相関係数は 


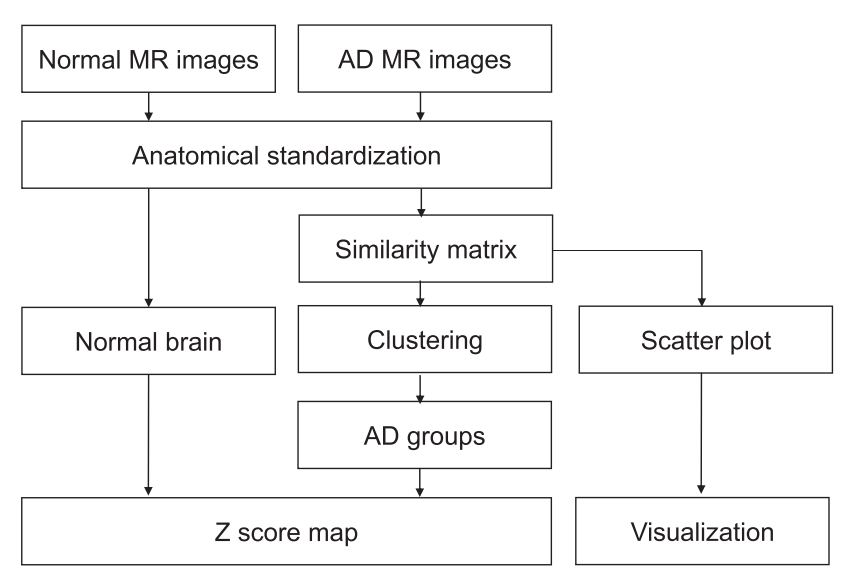

Fig. 1 Flowchart of the proposed method.

-1.0〜1.0 までの值を出力する. もし, 二つの画像の類 似度が高ければ相互相関係数は 1.0 に近い值を示し, 逆に，相違が大きければ-1.0に近い值を示す，画像 $A$ と画像 $B$ の相互相関係数 (cross-correlation coefficient: CC)は次式によって計算される.

$C C(A, B)=\frac{1}{I J K} \sum_{i=1}^{I} \sum_{j=1}^{J} \sum_{k=1}^{K} \frac{(A(i, j, k)-\bar{A})(B(i, j, k)-\bar{B})}{\sigma_{A} \sigma_{B}}$

ここで, $\bar{A}$ と $\bar{B}$ は画素の平均値を表し, $\sigma_{A}$ と $\sigma_{B}$ は標 準偏差をそれぞれ表す。また， $I ， J ， K$ は相互相関倸 数を計算する関心領域の範囲を示す。つまり, 本手法 では，関心領域を上式の $I, J, K$ によって指定される 立方体とする。もし，より複雑な関心領域を設定した い場合には，画像をラスタスキャンして複雑な関心領 域内となった画素の值を順番に並べ, 変数 $I$ のみで表

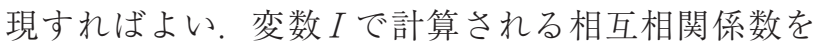
用いることで複雑な関心領域の分析も以下の方法で同 様に行うことができる。

上述した方法により画像間の類似度が計算可能とな るが，関心領域の設定の仕方には自由度があり，その 与え方によって分類の結果が変わる，そこで本実験で は, axial 方向, coronal 方向, 局所領域(部位)の三つ に関心領域を設定して類似度を計算した。

·条件 1：海馬を含む axial スライスを中心に, 6×95× 79 の大きさの関心領域を設定して類似度を計算し た場合.

·条件 2 : 海馬を含む coronal スライスを中心に, $68 \times$ 6×79 の大きさの関心領域を設定して類似度を計算 した場合.

・条件 3 ：海馬を囲むように, $6 \times 25 \times 50$ 大きさの局所 的な関心領域を設定して類似度を計算した場合。
脳形態標準化処理後の画像サイズは $68 \times 95 \times 79$ であ るから, 条件 1 の関心領域は画像の高さ (Y 軸) と幅 (X 軸) 方向に最大の大きさとして, 条件 2 の関心領域 は画像の深さ $(\mathrm{Z}$ 軸) と幅 $(\mathrm{X}$ 軸) 方向に最大の大きさと してそれぞれ設定した。また，対象となる領域を含む ように幅を 6 に設定した。

上記の三つの条件で計算されたそれぞれの類似度を 用いて階層的クラスタリング8) を行い，画像デー夕を 分類した。つまり, axial 方向の類似度による分類結 果, coronal 方向の類似度による分類結果, 海馬領域の 類似度による分類結果の三つを求めた。ここで，階層 的クラスタリングとは, 最も似ている画像データを順 次集め，樹形図のように類似症例を分類する手法であ る。本研究では, 階層的クラスタリングの方法として ウォード法を採用した。 ウォード法は, 二つのクラス 夕 X とクラス夕 Yをまとめる際に，その情報損失量 が最小のものをまとめる方法である ${ }^{8)}$. 階層的クラス タリングは, フリーソフトである $\mathrm{R}^{12)}$ を用いて行っ た ${ }^{13)}$ 。階層的クラスタリングの実行には，データ間の 距離(近さ)からなる距離行列を与える必要がある. 距 離行列では似ている症例間の距離は小さい值となる が，相互相関係数による類似度では逆に似ているほど 值が高くなる，そこで，以下の変換式を用いることで 距離行列を作成した。

\section{Distance Matrix ( $m, n)$}

$=2.0-($ Similarity Matrix $(m, n)+1.0)$

ここで, Distance Matrix $(m, n)$ は $m$ 番目と $n$ 番目の 症例の距離を表す。この変換式を用いることによっ て, 相互相関係数による類似度行列 (Similarity Matrix)の值が最も高い 1.0 のとき, 距離行列 (Distance Matrix)の值は 0.0 になる.

階層的クラスタリングによって分類された $\mathrm{AD}$ グ ループの特徵を可視化するために，Z スコアマップを 作成した。まず，健常者 30 症例の画像デー夕を 2-1 節の手法で脳形態標準化処理を行い, 脳形態を標準化 した 30 症例について平均值と標準偏差をボクセルご とに計算することによって正常脳の平均画像と標準偏 差画像を作成した，つぎに，階層的クラスタリングに よって分類された $\mathrm{AD}$ グループごとに平均画像を作 成した， $\mathrm{AD}$ グループの特徵が可視化できるように正 常脳との違いを以下の式で画像化した。

$$
Z_{-} \operatorname{Score}_{m}(x, y, z)=\frac{\operatorname{Mean}(x, y, z)-A D_{m}(x, y, z)}{S D(x, y, z)}
$$


Similarity matrix (1) (Axial direction)

\begin{tabular}{|c|c|c|c|c|}
\hline & $A$ & $B$ & $C$ & $D$ \\
\hline$A$ & 1.0 & & & \\
\hline$B$ & 0.2 & 1.0 & & \\
\hline C & 0.8 & 0.4 & 1.0 & \\
\hline D & 0.9 & 0.9 & 0.8 & 1.0 \\
\hline
\end{tabular}

Similarity matrix (2) (Coronal direction)

\begin{tabular}{|c|c|c|c|c|}
\hline & A & B & C & D \\
\hline A & 1.0 & & & \\
\hline B & 0.9 & 1.0 & & \\
\hline C & 0.8 & 0.5 & 1.0 & \\
\hline D & 0.1 & 0.9 & 0.2 & 1.0 \\
\hline
\end{tabular}

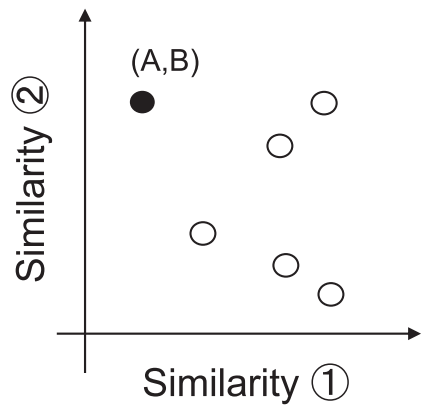
$a|b| c$

Fig. 2 Scatter plot for visualizing regularities and abnormalities in the image data sets.

ここで, $\operatorname{Mean}(x, y, z)$ と $S D(x, y, z)$ は正常脳の平均画 像と標準偏差画像をそれぞれ表し, $A D_{m}(x, y, z)$ は $m$ 番目のグループの平均画像を表す。この処理によっ て，自動分類された $\mathrm{AD}$ グループがどの部位で特徵的 な形態変化が起きているかを視覚的に分析することが できる。

\section{2-3 散布図による画像パターンの規則性と異常性の 分析}

画像デー夕間の規則性と異常性の関係を散布図に よって可視化する方法について述べる．2-2 節で(1)axial 方向の類似度, (2)coronal 方向の類似度, (3)部位の 類似度をそれぞれ計算した。いつかの類似度が求 まった場合に，(1)の類似度も(2)の類似度も高い，ある いは(1)の類似度は高いが(2)の類似度は低いといった分 析が必要になる。本論文では，それらの関係を散布図 で可視化する方法を提案する，ADNI データベースに は画像と遺伝子のセットがある。提案手法は, 例え ば，ある遺伝子をもつ症例ともたない症例を色分けし て表示することによって，画像所見と遺伝子の関係分 析にも応用できる。

Fig. $2 \mathrm{a}$ と b は(1)の類似度と(2)の類似度に関する画 像データ A から D までの類似度行列をそれぞれ示し ている，類似度行列では画像デー夕 A と画像デー夕 $\mathrm{B}$ の類似度は $\mathrm{A}$ 行 $\mathrm{B}$ 列の位置に与える。同じ画像 デー夕の類似度は 1.0 であり対角線上の值となる。類 似度行列は対称行列で表されるため, 下三角行列の值 のみを示す。まず，症例 $\mathrm{A}$ と B の類似度を見てみる

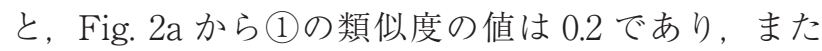
Fig. $2 \mathrm{~b}$ から(2)の類似度の值は 0.9 である。これらの值 を用いると Fig. $2 \mathrm{c}$ の二次元空間上の 1 点が定まり

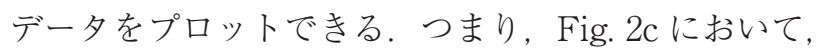
横軸を(1)の類似度, 縦軸を(2)の類似度とすれば, 画像 データ A と B の関係は $(0.2,0.9)$ の点で表現できる.
この図をみれば明らかなように, 画像デー夕 A と画 像データ B は(1)の類似度は低いが, (2)の類似度は高い 関係にあることが容易に理解できる，以下，同様の操 作を繰り返すと, Fig. 2c に示すように, すべての症例 のすべての組合せに対する類似度の関係を散布図で表 示することができる。この例のように, 症例 $\mathrm{A}$ と症 例 B の類似度が一つの場合には二次元空間にプロッ トすることはできない.しかし, 症例 $\mathrm{A}$ と症例 $\mathrm{B}$ の 異なる二つの部位で類似度を計算すれば，上記の手法 で二次元空間にその関係をプロットし，異なる部位の 萎縮パターンを可視化して比較できる，本手法によっ て作成した散布図を分析することによって，それぞれ の画像データに含まれる規則性と異常性を発見するこ とができる。

\section{3. 実験結果}

$\mathrm{AD}$ 患者画像 40 症例を axial 方向の類似度 (条件 1) を用いて階層的クラスタリングによって分類した結果 を 2.2 節で述べた Z スコアマップで表示したものを Fig. 3 に示す. グレースケール画像は各 $\mathrm{AD}$ グループ の平均画像を表している。青色は正常脳の平均画像よ り画素值が低く萎縮が起きている場所であり, 逆に, 赤色は正常脳の平均画像より画素値が高い場所を示し ている，グループ1では軽度の脳室拡大がみられる. グループ 2 では脳溝の軽度拡大があるが脳室の拡大は ほとんどみられない.グループ 3 では脳室と脳溝の軽 度拡大がみられる。グループ 4 では脳室と脳溝の拡大 および海馬の顕著な委縮がみられる。グループ 5 では 脳室と脳溝の拡大がみられるが, グループ 4 と比較す ると海馬の委縮の程度は軽度である。

つぎに, 同じ症例に対して coronal 方向の類似度 (条 件 2)を用いて階層的クラスタリングによって分類し た結果を Fig. 4 に示す.グループ 1 では脳溝の軽度拡 大がみられるが正常例に近い. グループ 2 では脳溝の 

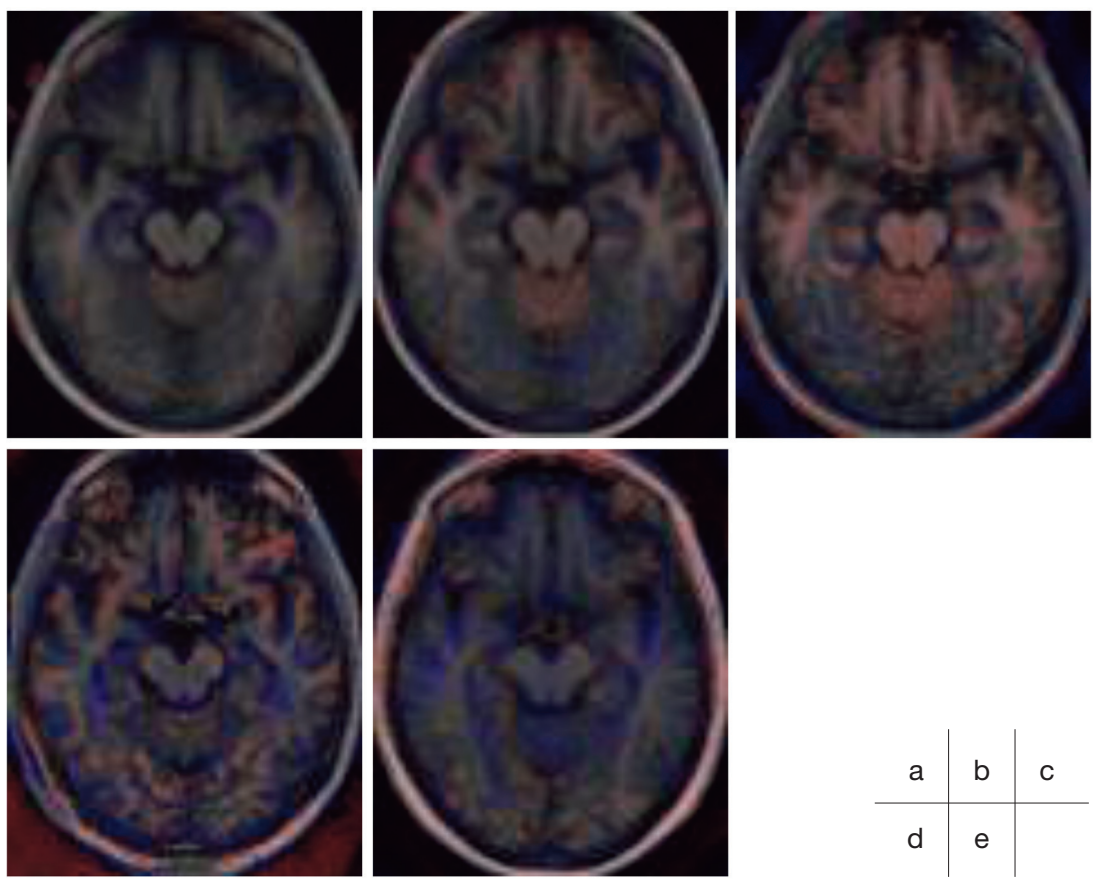

Fig. 3 Condition 1: Classification results by using the similarity in axial direction. (a) Group 1 (b) Group 2 (c) Group 3 (d) Group 4 (e) Group 5
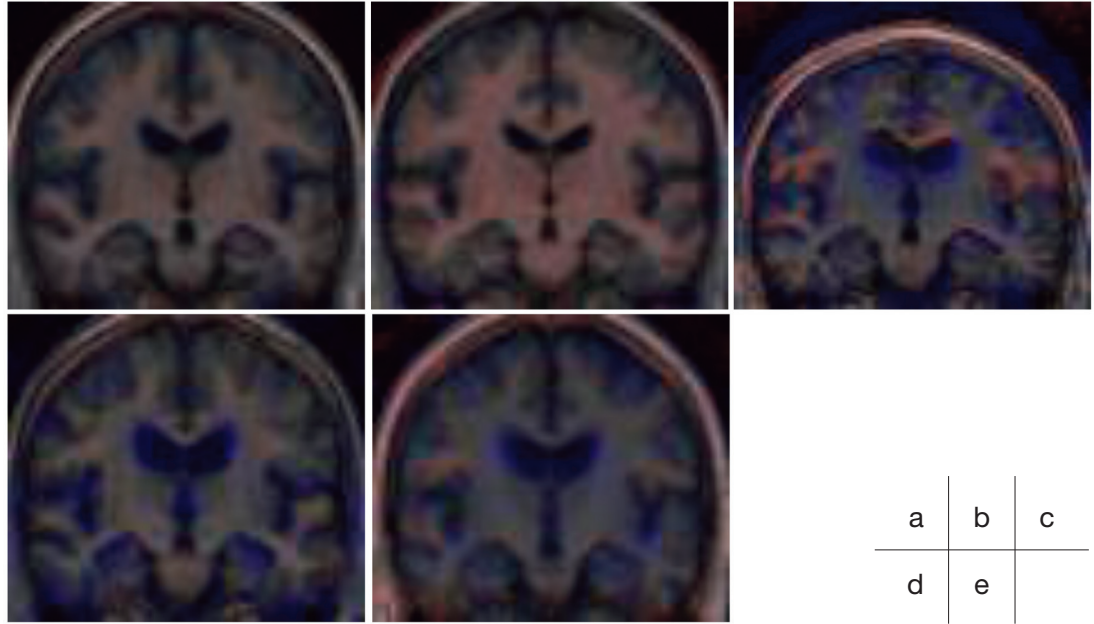

Fig. 4 Condition 2: Classification results by using the similarity in coronal direction. (a) Group 1 (b) Group 2 (c) Group 3 (d) Group 4 (e) Group 5

軽度拡大がみられるが脳室の拡大はほとんどない。グ ループ 3 の症例はSPM による位置合わせがうまく機 能せず全体として位置が下にずれたために，脳形態標 準化処理が正常に動作しなかった症例が同じグループ に分類されたと考えられる。画像デー夕に含まれる規 則性や異常性を分析する際に，前処理で用いた脳形態 標準化処理が正常に動作しなかった症例を取り除く作 業が必要になる。この例のように, SPM による位置 合わせが正常に動作しなかった症例が本手法によって 自動的に分類されれば，それらの症例を取り除くこと
が容易になる点も興味深い.グループ 4 では脳溝と脳 室の拡大および海馬の顕著な委縮がみられる。グルー プ5では脳室の拡大がみられるが，グループ4に比べ 脳溝の拡大と海馬の委縮の程度は軽度である。このよ うに，階層的クラスタリングで分類されたグループご とにZスコアマップで表示することによって，それぞ れのグループで, どの部位でどの程度の形態的な変化 が生じているかを視覚的に理解することができる。

画像デー夕間の規則性と異常性の関係を散布図に よって可視化した結果を Fig. 5 に示す. 図から判断で 


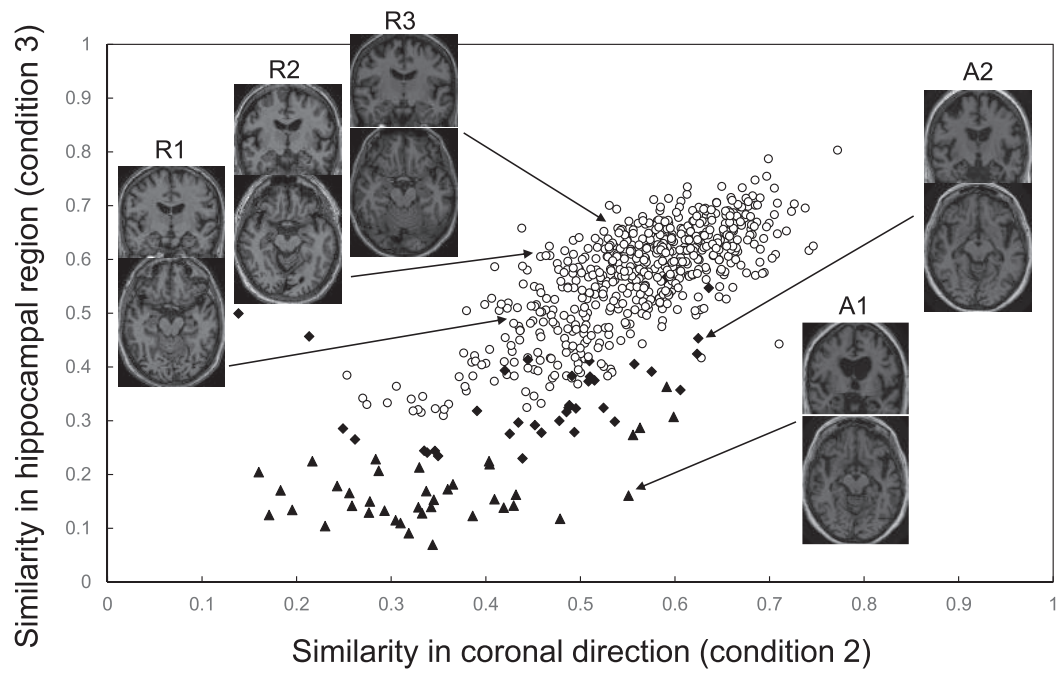

Fig. 5 Scatter plot for visualizing regularities (R) and abnormalities (A) in the image data sets.
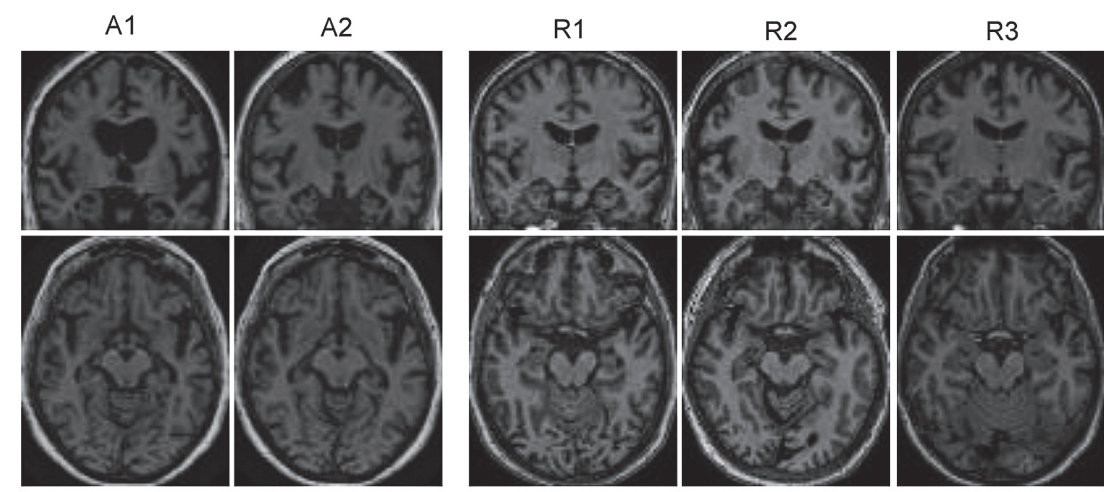

Fig. 6 Examples of abnormal patterns obtained by using scatter plot analysis.

きるように多くの症例では同じ萎縮パターンを持つ規 則性を示すが, A1 とA2 は他の萎縮パターンと違う 異常性を持っていることがわかる.A1の症例は coro$\mathrm{nal}$ 方向の類似度 (条件 2) と局所領域の類似度 (条件 3)のどちらの值も他の症例と顕著に異なる性質を持っ ていることが散布図から容易に読み取れる。また, A2 の症例も局所領域の類似度 (条件 3)で他の症例と 異なる性質を持つ傾向がある。これらの症例の画像を 拡大したものをFig. 6 に示す，図から明らかなよう に, これらの 2 症例は脳室の拡大や海馬領域に明らか な萎縮を見ることができる。このように，本手法を用 いることで画像デー夕に含まれる異常性を持つ個別の 症例を発見することができる。

\section{4. 考察}

本実験では, 相互相関係数を求める際の関心領域の 設定に三つの条件を設けた。関心領域の設定を変えて 階層的クラスタリングを適用した場合に，同じ症例は
同じグループに分類されるか否かを検討した. Table 1 は axial 方向の類似度 (条件 1) と coronal 方向の類似 度 (条件 2)によって分類されたグループの関係を示 L, Table 2 は coronal 方向の類似度 (条件 2) と海馬領 域の類似度 (条件 3)によって分類されたグループの関 係を示す。もし，関心領域の設定を変えても同じグ ループに分類されるならば，斜め対角線上に值が集ま るはずである。実験の結果, Table 1 では 17/40 症例 が対角線上に集まり，Table 2 では 19/40 症例が対角 線上に集まった。半分以下の症例しか対角線上に集ま らなかった結果から，関心領域の設定の仕方によって は，階層的クラスタリングの分類結果が異なることが 明らかになった。つまり，本手法を用いる場合には， 注目したい部位に関心領域を設定することが重要であ り，注意すべき点であると考察される。

核医学の分野では, 解剖学的標準化済みの single photon emission computed tomography (SPECT) 画像 に三次元定位の関心領域テンプレートを設定し, ROI 
Table 1 Number of cases classified by each of the similarity in axial direction and the similarity in coronal direction

\begin{tabular}{lcccccc}
\hline \hline & & \multicolumn{5}{c}{$\begin{array}{c}\text { Similarity in axial direction } \\
\text { (Condition 1) }\end{array}$} \\
\cline { 3 - 7 } & Group & G1 & G2 & G3 & G4 & G5 \\
\hline \multirow{3}{*}{ Similarity in } & G1 & 7 & 4 & 1 & 0 & 0 \\
coronal & G2 & 1 & 6 & 4 & 0 & 0 \\
direction & G3 & 1 & 0 & 0 & 2 & 0 \\
(Condition 2) & G4 & 4 & 1 & 1 & 0 & 0 \\
& G5 & 4 & 0 & 0 & 0 & 4 \\
\hline
\end{tabular}

Table 2 Number of cases classified by each of the similarity in hippocampal region and the similarity in coronal direction

\begin{tabular}{lcccccc}
\hline \hline & & \multicolumn{5}{c}{$\begin{array}{c}\text { Similarity in hippocampal region } \\
\text { (Condition 3) }\end{array}$} \\
\cline { 3 - 7 } & Group & G1 & G2 & G3 & G4 & G5 \\
\hline \multirow{3}{*}{ Similarity in } & G1 & 7 & 4 & 1 & 0 & 0 \\
coronal & G2 & 2 & 9 & 0 & 0 & 0 \\
direction & G3 & 1 & 0 & 2 & 0 & 0 \\
(Condition 2) & G4 & 1 & 4 & 1 & 0 & 0 \\
& G5 & 0 & 0 & 5 & 2 & 1
\end{tabular}

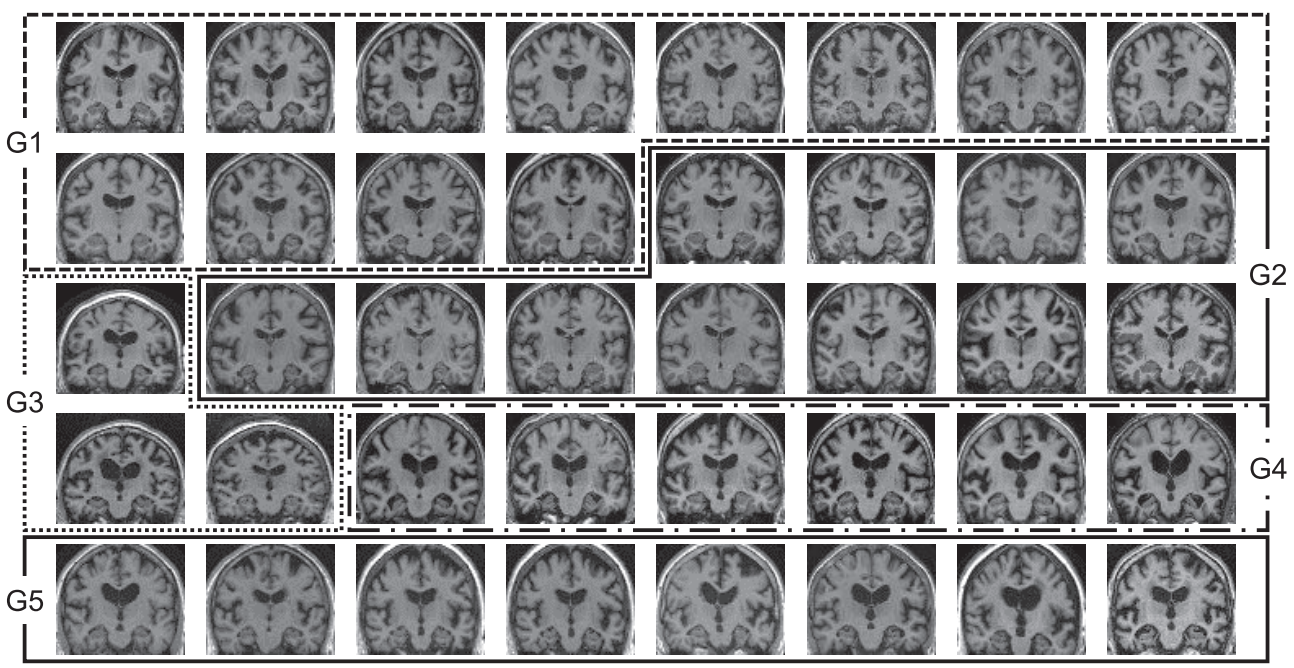

Fig. 7 The classification results of all 40 Alzheimer's disease (AD) cases by using hierarchical clustering technique.

内の值を比較する 3-dimensional stereotactic ROI template (3DSRT) が早い段階から用いられている年). 3DSRT を用いた解析では, 設定した ROI の位置と関 係する解剖学的多様性に関する客観的定量值を評価寸 ることができる。本手法においても，3DSRTで用い られているように多くの ROI を自動設定して，それ らの ROI から類似度を計算することによって，部位 ごとに類似した症例の自動分類や画像デー夕に潜んで いる異常性の分析も可能になると考えられる.

Computer-aided diagnosis (CAD) の研究 ${ }^{15)}$ では, 病 変の存在や良悪性を鑑別する際に，画像特徵量を抽出 し, 識別器を用いてそれらを判別するアプローチを用 いている。この機械学習とデータマイニングは同じ手 法が用いられる場合もあり，しばしば混同される。 CAD では, 病変か否か, あるいは良性か悪性かは「教 師デー夕」として事前にわかっており，これが gold standard として使用される。一方，データマニングの 目的は，それまでに未知だった画像デー夕に含まれる 関係を発見することであるため,「教師デー夕」は事前 に存在しない。したがって，本論文で提案した「教師
なし学習」の手法である階層的クラスタリングによる 分類結果を gold standard を用いて定量評価すること はできない. Fig. 7 に本手法によって分類した 40 例 の $\mathrm{AD}$ 症例すべての分類結果を示す。図から判断で きるように，階層的クラスタリングによって，これま で医師が主観的判断により手作業で行っていた分類作 業を自動で行うことができる点が提案手法の有用性で ある。これから個別化医療の実現に向けて遺伝子と画 像デー夕の関係性を調べる研究が進むと予想され

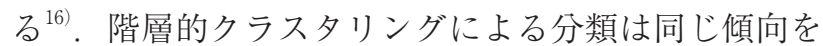
持ついくつかのグループの特性を理解するのに役立つ が，散布図による分析は個々の特性を理解するのに役 に立つ．個別化医療を支援するためのデー夕分析にお いては，これまでのように大きな集団としての特性を 分析する手法ではなく，個別のグループの特性を分析 する手法の開発が必要になる。本論文で提案した散布 図分析の手法を活用すれば，画像デー夕に含まれる異 常性を発見することができ，その患者の遺伝子の情報 と比較することができる。これらの関係が医学的観点 からも明らかになれば，将来の遺伝子診断の結果をも 
とに，萎縮が早期に起きる部位を特定し，その変化を 定量評価する個別化医療を支援するための次世代 CAD が開発できる。

\section{5. 結 語}

脳 MR 画像の形態変化のパターンを自動分類し, 可 視化する画像データマイニング技術を提案した，本手 法を適用することによって, 画像特徴の規則性や異常 性を発見することができる。ポストゲノム時代に入 り, imaging phenotypeを中心に進められてきた放射 線医学の研究に genotype という新しい視点を加える radiogenomics と呼ぶ新しい研究領域が形成されつつ
ある．本手法は遺伝子と画像所見の関係を分析する際 の画像特徴量の定量化と類似度の分析方法を提案した ものであり, radiogenomics 研究の一手法としての活 用が期待できる。

\section{謝 辞}

本研究の一部は, 科学研究費基盤研究 $\mathrm{C}$ (課題番号 24591815)によって行われました。

な㧍, 本研究の要旨は第 71 回日本放射線技術学会 総会学術大会(2015 年, 横浜)にて発表した。

\section{参考文献}

1）池田 学 編. 認知症 臨床の最前線. 東京: 医歯薬出 版, 2012.

2) Goldenberg R, Kimmel R, Rivlin E, et al. Cortex segmentation : A fast variational geometric approach. IEEE Trans Med Imaging 2002; 21: 258-296.

3) Arimura H, Yoshiura T, Kumazawa S, et al. Automated method for identification of patients with Alzheimer's disease based on three-dimensional MR images. Acad Radiol 2008; 15(3): 274284.

4) Jones SE, Buchbinder BR, Aharon I. Three-dimensional mapping of cortical thickness using Laplace's equation. Hum Brain Mapp 2000; 11(1): 12-32.

5) Hirata $Y$, Matsuda $H$, Nemoto $K$, et al. Voxel-based morphometry to discriminate early Alzheimer's disease from controls. Neurosci Lett 2005; 382(3): 269-274.

6）石川 博, 新美礼彦, 白石 陽, 他. データマイニングと 集合知. 東京：共立出版, 2012 .

7）元田 浩, 津本周作, 山口高平, 他. データマイニングの 基礎．東京：オーム社, 2006.

8）宮本定明. クラスター分析入門。東京：森北出版, 1999.
9）ADNI, http: //adni.loni.usc.edu/, 最終アクセス日 2015 年 6 月 26 日。

10） SPM, http: //www.fil.ion.ucl.ac.uk/spm/, 最終アクセス日 2015 年 6 月 26 日.

11）菊池吉晃, 妹尾淳史, 安保雅博, 他. SPM8 脳画像解析又 ニュアル。東京：医歯薬出版, 2012.

12） R, http: //www.r-project.org/, 最終アクセス日 2015 年 6 月 26 日。

13）金 明哲. Rによるデータサイエンス. 東京 : 森北出版, 2007.

14）竹内 亮. 脳核医学画像全自動 ROI 解析プログラム 3DSR. 日放技学誌 2003; 59(12): 1462-1474.

15) Doi K. Computer-aided diagnosis in medical imaging: historical review, current status and future potential. Comput Med Imaging Graph 2007; 31 (4-5): 198-211.

16) Li H, Giger ML, Sun C, et al. Pilot study demonstrating potential association between breast cancer image-based risk phenotypes and genomic biomarkers. Med Phys 2014; 41(3): 03197. 